\title{
MOLECULAR IDENTIFICATION OF Aeromonas hydrophila STRAINS RECOVERED FROM KAFRELSHEIKH FISH FARMS
}

\author{
Ahmed Mansour ${ }^{1 *}$, Nadia B. Mahfouz ${ }^{2}$, Mona M. Husien ${ }^{1}$, Mohammed A. El-Magd ${ }^{3}$ \\ ${ }^{1}$ Fish Diseases Research Department, Animal Health Research Institute, Agricultural Research \\ Center, Dokki, Giza, Egypt, ${ }^{2}$ Department of Fish Diseases and Management, Faculty of Veteri- \\ nary Medicine, Kafrelsheikh University, Egypt, ${ }^{3}$ Department of Anatomy and Embryology, Faculty \\ of Veterinary Medicine, Kafrelsheikh University, Egypt
}

*Corresponding author, E-mail: drahmed_1986@hotmail.com

\begin{abstract}
The aim of this study was to recover Aeromonas hydrophila from Kafrelsheikh tilapia (Oreochromis niloticus) farms and to study its virulence. Adult fish $(n=100)$ exhibiting the onset of clinical signs were bacteriologically examined using aeromonas isolation base medium. The isolates were identified by PCR using $A$. hydrophila-specific 16S rRNA primers and the virulence was determined using specific primers for ten virulence genes targeting hidrolipase (Lip), elastase (ahyB), lipase (pla/lip), aerolysin (aer), cytotonic enterotoxin (alt), cytotoxic enterotoxin (act), temperature sensitive protease (eprCAl), serine protease $(A h p)$, haemolysin $(h l y A)$, and cytotonic heat stable enterotoxin (ast). Molecular screening revealed presence of 35 isolates positive for $A$. hydrophila-specific 16S rRNA and 4 virulence genes (aer, pla/lip, ast, and $h l y A$ ). It also showed that the majority of the examined strains carried one or more virulence genes. These data indicate higher virulence for $A$. hydrophila in infected $O$. niloticus in Kafrelsheikh fish farms.
\end{abstract}

Key words: PCR; A. hydrophila; virulence genes

\section{Introduction}

Fish provide cheap healthy protein source to human especially in coast countries, such as Egypt. Therefore, it is not strange to find a fast increase in aquaculture production sector in Egypt during the last two decades. However, this huge aquaculture resulted in elevation of prevalence, pathogenicity, and drug resistance of some bacteria strains. Aeromonas hydrophila, a motile opportunistic aeromonad that normally lives in fish gut, is one of the most common bacteria infected a large variety of fish (including marine and fresh water fish), especially those reared in aquaculture where they subjected to many stressors (inadequate $\mathrm{PH}$, extreme temperature, hypoxia, malnutrition) mainly caused by overcrowding. These stressors depress fish immunity and allow this opportunistic aeromonad to invade fish causing hemorrhagic septicemia or motile aeromonas septicemia (MAS) characterized by high morbidity and mortality thereby leading to severe economic loss to fisheries (1). The typical symptoms of this disease include tail rot, hemorrhage, ulcer and scale desquamation and exophthalmia (2).

To achieve appropriate treatment for bacterial diseases, we should first accurately identify 
not only the bacterial species but also their strains and serotypes. Unlike other animals, there some limitations regarding diagnosis of bacterial pathogens in fish due to lack of rapid, sensitive and accurate means by which fish pathogens can be detected. Although, most of bacteria can be successfully isolated following their culture on specific media, this traditional method of diagnosis failed to accurately differentiate between different strains and serotypes $(2,3)$. In contrast, molecular based identification can accurately identify different bacterial strains and serotypes quickly, more specifically and in a more sensitive and reliable way. Polymerase chain reaction (PCR) was successfully applied to not only detect bacterial pathogens in fish but also differentiate between different bacterial strains and serotypes (3-7). Therefore, this study was designed to screen for prevalence of $A$. hydrophila virulent strains in Kafrelsheikh governorate $O$. niloticus farms.

\section{Materials and methods}

\section{Sampling and bacteriological examination}

Fish $(n=100)$ showing clinical signs of skin hemorrhages were aseptically streaked on tryptic soy agar and sub-cultured until obtaining pure colonies then tested on aeromonas isolation base medium to monitor the characteristic bull eye shaped colonies. All bacterial cultures were incubated at $28^{\circ} \mathrm{C}$ for 24 hours. The biochemical tests were done using commercially available API20NE (Biomerieux ${ }^{\circledR}$, France).

\section{DNA extraction and PCR amplification}

DNA extraction were done by thermolysis after culturing of bacterial strains on brain heart infusion broth and incubated at $37^{\circ} \mathrm{C}$ for 12 hours in shaker incubator. PCR amplification of
A. hydrophila specific-16S rRNA gene and virulent genes was performed in thermal cycler using $25 \mu 1$ mixture containing $0.5 \mu 1$ DNA polymerase $(5 \mathrm{U} / \mathrm{ml}), 2.5 \mu \mathrm{l} 10 \mathrm{X}$ PCR buffer, $2.5 \mu \mathrm{l}$ dNTP mixture, $1 \mu \mathrm{l}$ of each primer $(20 \mathrm{pmol} /$ $\mu \mathrm{l}$, Table 1), $5 \mu \mathrm{l}$ genomic DNA, and $12.5 \mu \mathrm{l}$ DNAse free water. PCR conditions were done as previously described (4-7).

\section{Results}

Bacterial culturing revealed isolation of 35 isolates of A. hydrophila from 100 fish showing typical A. hydrophila clinical signs. The isolated bacterial colonies were creamy-white, circular and convex, and 2-3 $\mathrm{mm}$ in diameter on TSA agar plates and resembled bull eye shape with dark green center and light periphery on aeromonas isolation base medium (Fig. 1).

Molecular characterization confirmed detection of 35 isolates positive to $16 \mathrm{~S}$ rRNA gene with a size of $103 \mathrm{bp}$ (Fig. 2). Among the screened 10 virulence genes; only 4 genes (pla/lip, ast, aer and hlyA) were found in 21 out of 35 isolates and were distributed as follow: pla/lip, ast, aer and hlyA in 5 isolates; pla/lip, aer, and ast in 7 isolates; pla/lip and aer in 6 isolates and pla/lip in 3 isolates. Fourteen strains were free from any virulence genes. The prevalence of $A$. hydrophila virulence genes among the virulent strains were distributed as follow: $100 \%$ (21/21) for pla/lip, 57\% (12/21) for ast, 86\% (18/21) for aer and 24\% (5/21) for hlyA (Tables 2 and 3; Figs. 3-6). Depending on the frequency of the virulence genes in positive A. hydrophila strains, the genotypes carrying virulence genes represent $(60.7 \%)$, while the genotypes free from virulence genes represent (39.4\%). 
Table 1: Primers used for detection of A. hydrophila virulence genes

\begin{tabular}{|c|c|c|c|}
\hline Gene & $\begin{array}{l}\text { Primers } \\
5^{\prime} \rightarrow 3^{\prime}\end{array}$ & $\begin{array}{l}\text { Size } \\
(\mathrm{bp})\end{array}$ & References \\
\hline $16 \mathrm{~S}$ rDNA & $\begin{array}{l}\text { F: GGCCTTGCGCGATTGTATAT } \\
\text { R: GTGGCGGATCATCTTCTCAGA }\end{array}$ & 103 & (7) \\
\hline Hidrolipase (Lip) & $\begin{array}{l}\text { F:AACCTGGTTCCGCTCAAGCCGTT } \\
\text { R:TTGCTCGCCTCGGCCCAGCAGCT }\end{array}$ & 65 & (6) \\
\hline Elastase $(a h y B)$ & $\begin{array}{l}\text { F: ACACGGTCAAGGAGATCAAC } \\
\text { R: CGCTGGTGTTGGCCAGCAGG }\end{array}$ & 540 & \\
\hline Lipase (pla/lip) & $\begin{array}{l}\text { F: ATCTTCTCCGACTGGTTCGG } \\
\text { R: CCGTGCCAGGACTGGGTCTT }\end{array}$ & $383-389$ & \\
\hline Aerolysin (aer) & $\begin{array}{l}\text { F: CCTATGGCCTGAGCGAGAAG } \\
\text { R: CCAGTTCCAGTCCCACCACT }\end{array}$ & $431-1987$ & \\
\hline $\begin{array}{l}\text { Cytotonic entero- } \\
\text { toxin }(a l t)\end{array}$ & $\begin{array}{l}\text { F: TGACCCAGTCCTGG } \\
\text { R: GGTGATCGATCACC }\end{array}$ & 442 & (5) \\
\hline $\begin{array}{l}\text { Cytotoxic entero- } \\
\text { toxin }(a c t)\end{array}$ & $\begin{array}{l}\text { F: GAGAAGGTGACCACCAAGAACA } \\
\text { R: AACTGACATCGGCCTTGAACTC }\end{array}$ & 232 & \\
\hline $\begin{array}{l}\text { Temperature sensi- } \\
\text { tive protease } \\
(\text { eprCAI) }\end{array}$ & $\begin{array}{l}\text { F: GCTCGACGCCCAGCTCACC } \\
\text { R: GGCTCACCGCATTGGATTCG }\end{array}$ & 387 & \\
\hline $\begin{array}{l}\text { Serine } \quad \text { protease } \\
(A h p)\end{array}$ & $\begin{array}{l}\text { F: ATTGGATCCCTGCCTA } \\
\text { R: GCTAAGCTTGCATCCG }\end{array}$ & 911 & \\
\hline Haemolysin $(h l y A)$ & $\begin{array}{l}\text { F: GGCCGGTGGCCCGAAGATACGGG } \\
\text { R: GGCGGCGCCGGACGAGACGGGG }\end{array}$ & 392 & \\
\hline $\begin{array}{l}\text { Cytotonic heat stable } \\
\text { enterotoxin (ast) }\end{array}$ & $\begin{array}{l}\text { F: TCTCCATGCTTCCCTTCCACT } \\
\text { R: GTGTAGGGATTGAAGAAGCCG }\end{array}$ & 331 & (4) \\
\hline
\end{tabular}

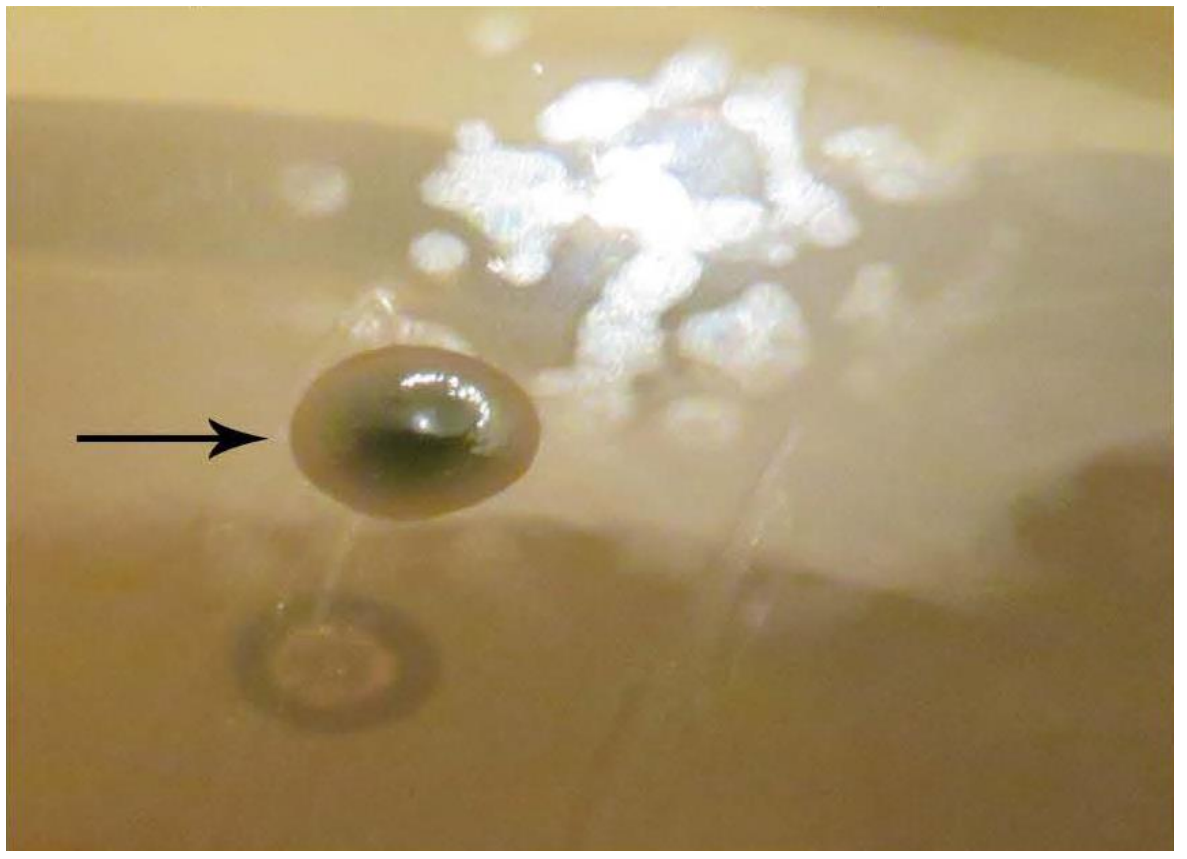

Figure 1: Characteristic bull eye shaped colony on aeromonas isolation base medium showing dark green convex center with light periphery 

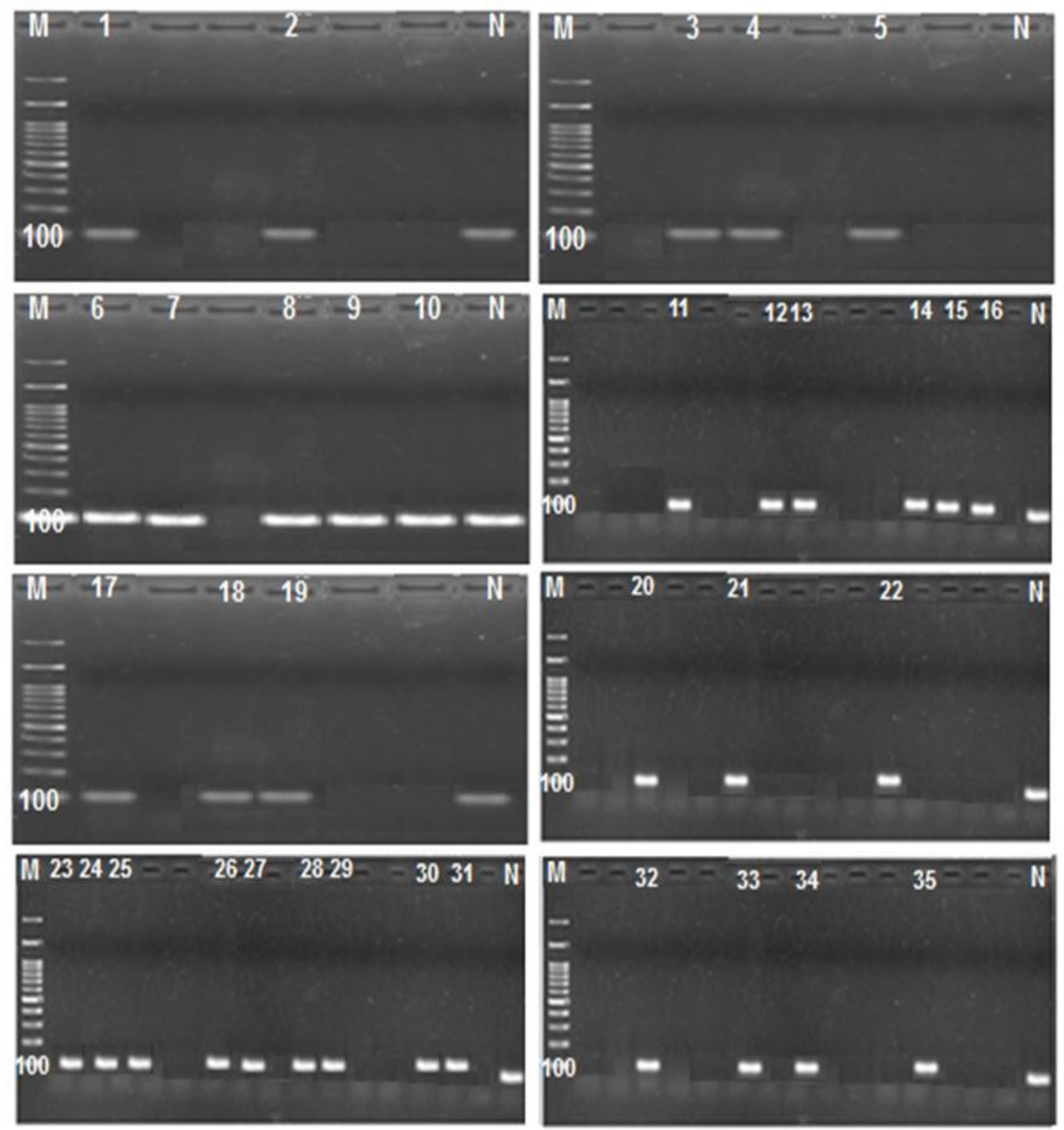

Figure 2: Electrophoretic pattern of PCR production $103 \mathrm{bp}$ specific for A. hydrophila in 2\% agarose gel stained with ethidium bromide. Lane M: 100 bp DNA ma Lane N: negative control . Lane 1- 35: positive A. hydrophia 

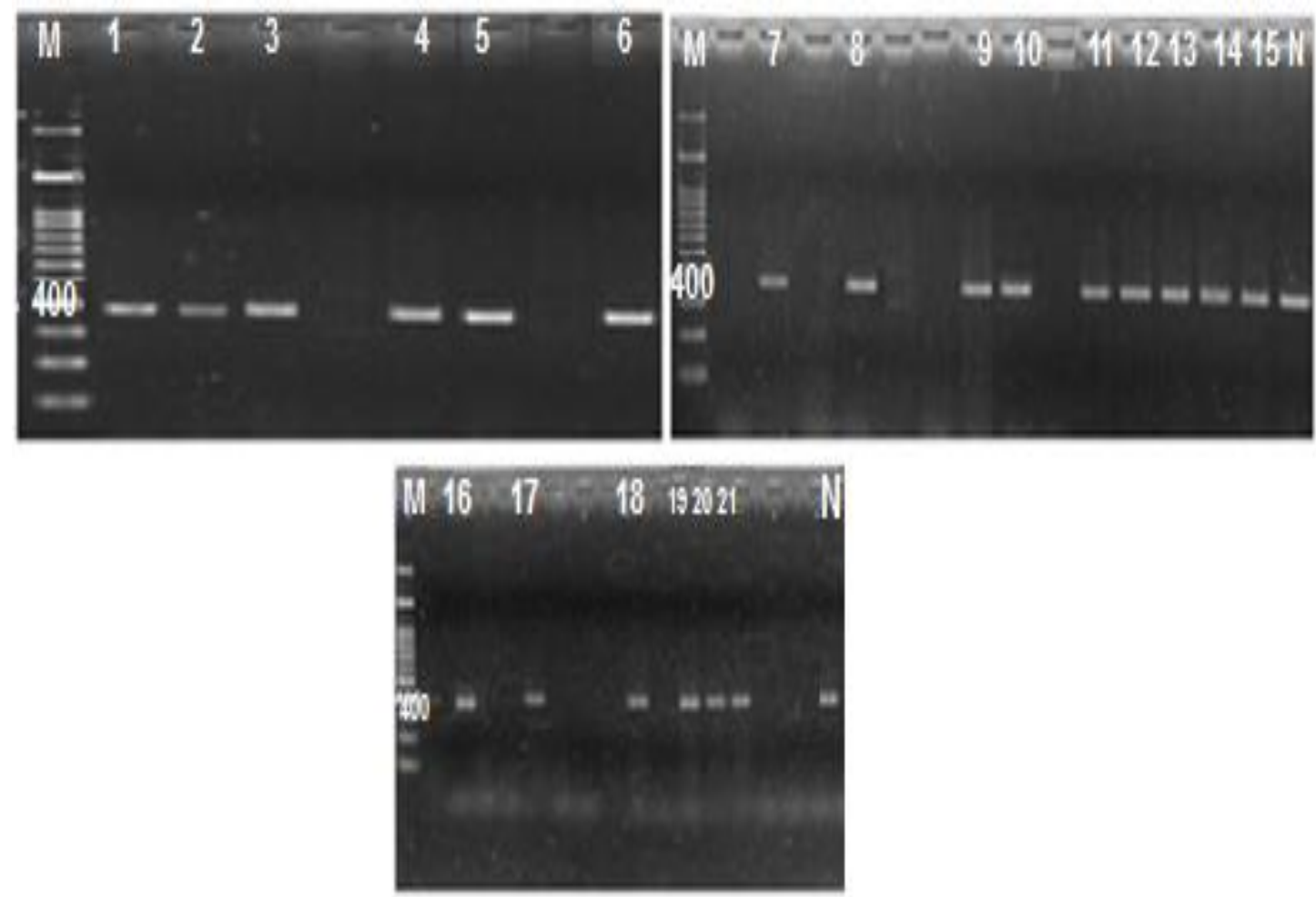

Figure 3: Ethidium bromide stained agarose gel of PCR products representing amplification of 383-389 bp amplicon of the pla/lip gene in A. hydrophila. Lane M: 100 bp DNA marker, Lane N: negative control, Lane 1- 25: positive
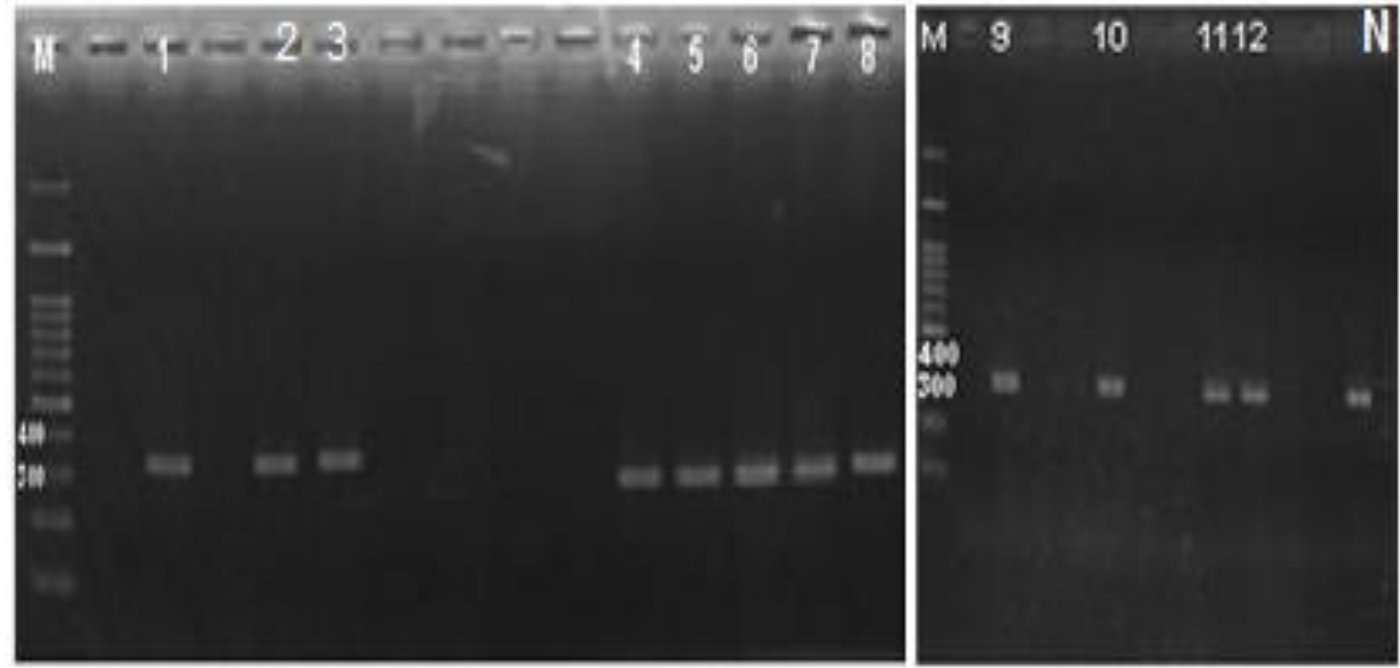

Figure 4: Ethidium bromide stained agarose gel of PCR products representing amplification of $328 \mathrm{bp}$ amplicon of ast gene in A. hydrophila. Lane M: 100 bp DNA marker, Lane N: negative control , Lane 114: positive 

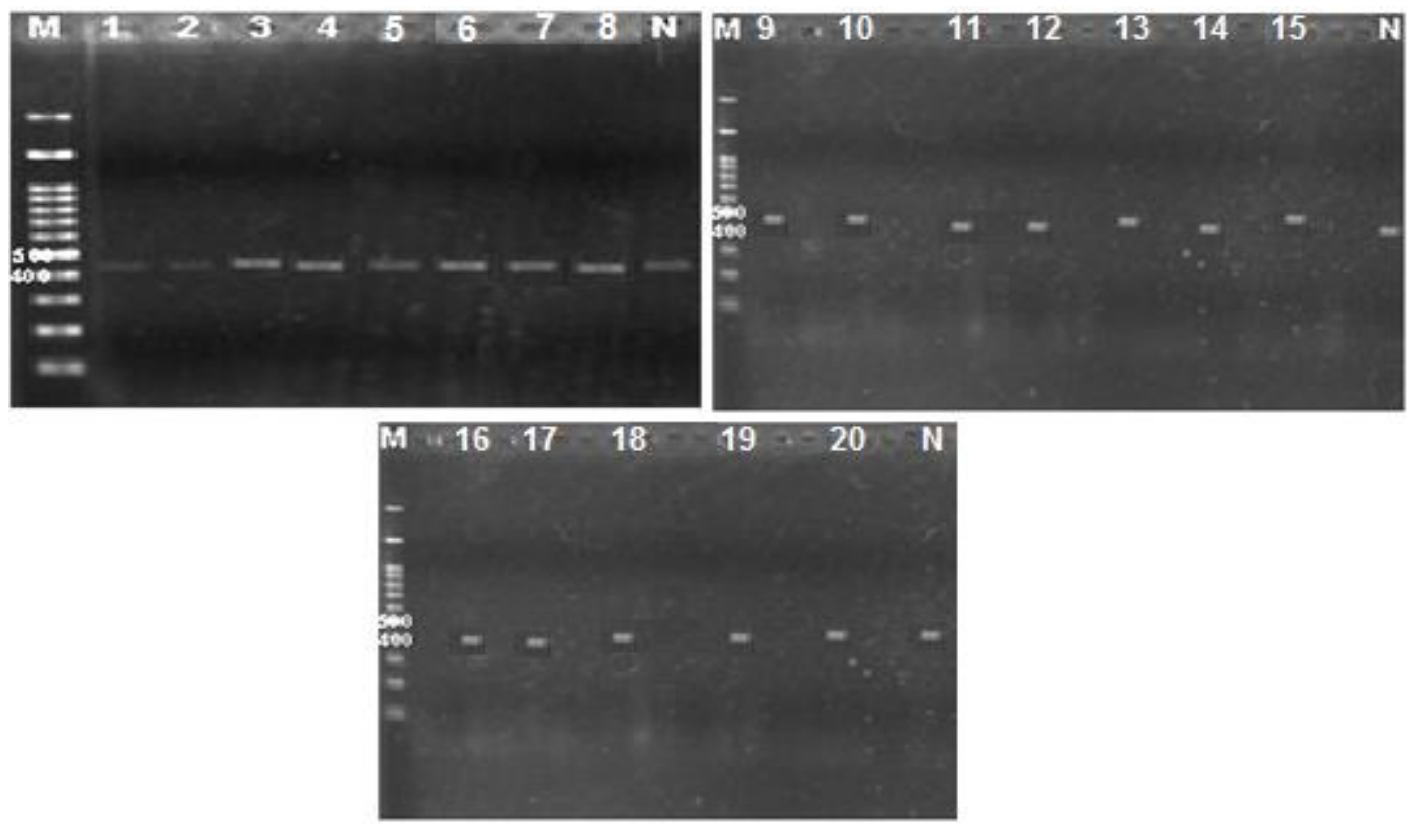

Figure 5: Ethidium bromide stained agarose gel of PCR products representing amplification of $431 \mathrm{bp}$ amplicon of aer gene in A. hydrophila. Lane M: 100 bp DNA marker, Lane N: negative control Lane 1- 8: positive

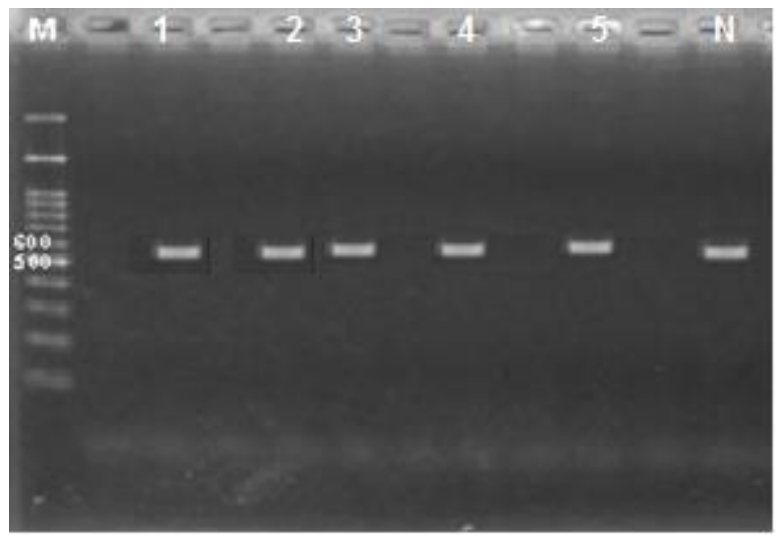

Figure 6: Ethidium bromide stained agarose gel of PCR products representing amplification of $592 \mathrm{bp}$ amplicon of the haemolysin (hlyA) gene in A. hydrophila .Lane M: 100 bp DNA marker .Lane N: negative control, Lane 1- 2: positive

Table 2: List of virulence genes present in the isolated Aeromonas hydrophila strains

\begin{tabular}{|l|l|l|l|}
\hline Gene & $\begin{array}{l}\text { Number of } \\
\text { isolates }\end{array}$ & $\begin{array}{l}\text { Occurrence } \\
(\%) \text { in isolated } \\
\text { strains }\end{array}$ & $\begin{array}{l}\text { Occurrence } \\
(\%) \text { in viru- } \\
\text { lent strains }\end{array}$ \\
\hline pla/lip & 21 & $60 \%$ & $100 \%$ \\
\hline ast & 12 & $34 \%$ & $57 \%$ \\
\hline hlyA & 5 & $14 \%$ & $24 \%$ \\
\hline aer & 18 & $51 \%$ & $86 \%$ \\
\hline
\end{tabular}


Table 3: Occurrence and combination of virulence genes in A. hydrophila strains

\begin{tabular}{|l|l|l|l|}
\hline Gene & $\begin{array}{l}\text { Number of } \\
\text { isolates }\end{array}$ & $\begin{array}{l}\text { Occurrence } \\
(\%) \text { in isolated strains }\end{array}$ & $\begin{array}{l}\text { Occurrence } \\
(\%) \text { in } \\
\text { virulent strains }\end{array}$ \\
\hline pla/lip, ast, aer, hlyA & 5 & $14 \%$ & $24 \%$ \\
\hline pla/lip, ast, aer & 7 & $20 \%$ & $33 \%$ \\
\hline pla/lip, aer & 6 & $17 \%$ & $29 \%$ \\
\hline pla/lip & 3 & $10 \%$ & $14 \%$ \\
\hline
\end{tabular}

\section{Discussion}

In developing coast countries, aquaculture is very important as a good source for animal protein suitable for human consumption $(8,9)$. This source was threatened by uncontrollable bacterial diseases especially for those caused by drug resistance bacteria and highly virulent bacteria such as A. hydrophila $(10,11)$.

PCR used in diagnosis of bacterial fish diseases, isolated from cultured fish, is a very rapid and accurate method $(6,12,13)$. The molecular identification of DNA for 35 A. hydrophila isolates, using specific primers revealed the presence of common band at $103 \mathrm{bp}$. These results were similar to that reported by (7).

Virulence genes act as a key component in determining the potential pathogenicity of the micro-organism, acting multifunctionally and multifactorially and can be used for virulence typing of $A$. hydrophila isolates (2, 6, 14). Herein, we isolated 10 virulence genes from the positive 35 A. hydrophila isolates by PCR. The virulence genes in Aeromonas hydrophila isolates, were distributed into, fourteen isolates $(40 \%)$, have no virulence genes while, twentyone $(60 \%)$ isolates have at least one or more virulence genes.

From the present work, it was evident that, the lipase (pla/lip) was the most frequent and important virulence gene. Lipase has the potential to change the histochemical identity of the cell membrane of the infected cells of target fish tissues thereby allowing A. hydrophila colonization which further induce cell necrosis (6, $15)$. The second more prevalent virulent gene was the aerolysin (aer) indicating high RBCs and cellular lysis for this bacteria (16). Presence of aerolysin in pathogenic $A$. hydrophila infections may help in diagnosis, prevention and control of the disease spreading and mortalities in aquaculture $(1,17)$. On the other hand, the prevalence of the cytotonic heat stable enterotoxin (ast) was lower than aer but higher than hemolysin. The ast has the ability to increase the vascular permeability of the gut causing detachment of the intestinal mucosa (18). Hemolysin $(h l y A)$ induced lytic activities on red blood cells, causing anemia (1). Haemolytic toxins; haemolysin and aerolysin released by $A$. hydrophila may be used as a marker of pathogenicity of $A$. hydrophila (1)

\section{Conflict of interest}

The authors declare that no conflict of interest.

\section{References}

1. Al-Maleky G M, Karim RM and Al-Abresm A N. Survey of Aeromonas hydrophila in Three Marine Fish Species from North West Arabian Gulf, Iraq. Bas.J.Vet.Res. 2011; 10 (2): 72-7.

2. Citarasu T, Alfred DK, Velmurugan S, et al. Isolation of Aeromonas hydrophila from Infected Ornamental fish Hatchery during Massive Disease Outbreak. International Journal of Current Research 2011; 2 (1): 037-41.

3. Frans I, Lievens B, Heusdens C, Willems KA. Detection and Identification of Fish Pathogens: What is the Future? The Israeli Journal of Aquaculture - Bamidgeh 2008; 60 (4): 213-29.

4. Balsalobre LC, Dropa M, Matte GR and Matte MH. Molecular detection of enterotoxins in environmental strains of Aeromonas hydrophila and Aeromonas jandaei. Journal of Water and Health 2009; 7(4): 685 -91.

5. Hu M, Wang N, Pan Z, Lu Cand Liu Y. Identity and Virulence Properties of Aeromonas Isolates 
from Diseased fish, Healthy Control and Water Environment in China. Letters in Applied Microbiology 2012; (55): 224-33.

6. Oliveira S, Veneroni- Gouveia G and Costa M. Molecular Characterization of Virulence Factors in Aeromonas hydrophila Obtained from Fish. Pesquisa Veteriinaria Brasileira 2012; 32 (8): 701-6.

7. Trakhna C, Harf-Monteil A, AbdelNour A et al. Rapid Aeromonas hydrophila identification by TaqMan PCR assay: comparison with a phenotypic method. Letters in Applied Microbiology 2009; 49: 186-90.

8. Nielsen M, Hoi L, Schmidt A et al. Is Aeromonas hydrophila the dominant motile Aeromonas species that disease outbreaks in aquaculture production in the Zhejiang Province of China? Diseases of Aquatic Organismis 2001; 46:23-9.

9. Abbas E, Soliman T, El-Magd M, et al. Phylogeny and DNA Barcoding of the Family Sparidae Inferred from Mitochondrial DNA of the Egyptian Waters. Journal of Fisheries and Aquatic Science 2017; 12, 73-81.

10. Mendez J, Reimundo P, Pérez-Pascual, D, et al. An Overview of Virulence-Associated Factors of Gram-Negative Fish Pathogenic Bacteria, Health and Environment in Aquaculture, Dr. Edmir Carvalho (Ed.) 2012; 133-56.

11. Yogananth N, Bhakyaraj R, Chanthuru A et al. Detection of Virulence Gene in Aeromonas hydrophila Isolated from Fish Samples Using PCR Technique. Global Journal of Biotechnology \& Biochemistry 2009; 4 (1): 51-3.
12. Hidalgo R and Figueras M. Aeromonas spp. whole genomes and virulence factors implicated in fish disease. Journal of Fish Diseases 2013; 36: 371-88.

13. El-Adawy M, El-Aziz M, El-Shazly, K, Ali N, El-Magd MA. Dietary propionic acid enhances antibacterial and immunomodulatory effects of oxytetracycline on Nile tilapia, Oreochromis niloticus. Environmental Science and Pollution Research 2018; 1-12.

14. Li L, Ni X, Liu Y, and Lu C. Detection of three virulence genes alt, ahp and aerA in aeromonas hydrophila and their relationship with actual virulence to zebra fish. Journal of Applied Microbiology 2011; 110: 823-30.

15. Zhang Y, Ong C and Leung K. Molecular analysis of genetic differences between virulent and avirulent strains of Aeromonas hydrophila isolated from diseased fish. Microbiology 2000; 146: 9991009.

16. Niamah AK. Detection of AERO gene in Aeromonas hydrophila isolated from shrimp and peeled shrimp samples in local markets. Journal of Microbiology, Biotechnology and Food sciences 2012; 2 (2): 634-39.

17. Singh V, Somvanshi P, Rathore G, et al. Gene Cloning, Expression, and Characterization of Recombinant Aerolysin from Aeromonas hydrophila. Appl Biochem Biotechnol 2010; 160:1985-91.

18. Harikrishnan R and Balasundaram C. Modern Trends in Aeromonas hydrophila Disease Management with Fish. Reviews in Fisheries Science 2005; 13:281-320. 